\title{
Some important elements of soil-water relationship in managing oil palms planted on acid sulfate soils
}

\section{Introduction}

Oil palms (Elaeis guineensis) are generally able to grow economically and feasibly on various soil types, mostly in tropical countries. However, oil palms planted on acid sulfate soils were producing lesser Fresh Fruit Bunches (FFB) as compared to those on non-acid sulfate soils. The poor performance of oil palms planted on acid sulfate was mainly attributed to the presence of excess sulfates, which limits the FFB yields and vegetative growth. ${ }^{1}$ Generally, acid sulfate soils have significant amounts of free and absorbed sulfate. Jarosite generally occurs as pale yellow mottles along old root channels and on ped faces in acid sulfate soils. $\mathrm{pH}$ in these horizon is less than 4.0..$^{2,3}$ These soils often are also high in Aluminium (Al), Al saturation and often with phosphorus (P) fixation capacity. These acid sulfate soils are known for having poor values for organic matter, bases, cation exchange capacity, water retention, water holding capacity and microbial activity, which contributes towards their low soil fertility and hence limitations in soil productivity. Of these limitations, Al toxicity and excess sulfates are two major constraints to FFB yields in oil palms. The important relationship of soil and water for managing a sustainable productivity of oil palms on acid sulfate soil are discussed in details in this paper.

\section{Methodology}

FFB yields in oil palms are usually expressed in metric tonnes per hectare (mt/ha). Such FFB yield recordings of oil palms that grown on acid sulfate soils at commercial scale, were gathered from Malaysia and Indonesia. For Malaysia, details of FFB yields were obtained from oil palm plantations in Carey Island, Kuala Kurau and Sepang areas in Malaysia. ${ }^{4}$ Meanwhile FFB yield recordings from Kebun TPAI were used for Indonesia. ${ }^{5}$ FFB yield recordings from both countries were referred to for a comparison.

\section{Characteristics of acid sulfate soils}

Acid sulfate soils are known for having problems in terms of chemical, biological and physical properties. ${ }^{6}$ Several researchers on the suitability of acid sulfate soils for an agricultural use had highlighted the following characteristics of acid sulfate soils. ${ }^{7-10}$

I. Potential Acid Sulfate Soils (higher pyrite fess) are often waterlogged in their natural state and thus, drainage is required before oil palm cultivation.

II. Draining of water below the pyrite layer would generate an excessive acidity, often dropping $\mathrm{pH}$ values to below 3.0. Such low $\mathrm{pH}$ is detrimental to any normal functions of oil palm roots and vegetative growth. Furthermore, oil palms would suffer from hyperacidity symptoms, resulting in poor FFB yields.

III. At such low soil pH, the degree of Aluminum (Al) solubility is increased and thus, its toxicity levels are most pronounced. For the same reason, solubility and toxicity of ferric, manganese and hydrogen ions also increased, causing poor vegetative growth as well as poor FFB yields in oil palm.
Volume 4 Issue 6 - 2020

\author{
UT Pupathy, ' T Sabrina, ${ }^{2}$ S Paramananthan, ${ }^{3}$ \\ Rosazlin Abdullah ${ }^{4}$ \\ 'Sumber Tani Agung (STA) Resources, Jn Dipronegoro 5I, \\ Medan, 20152, Sumatra, Indonesia \\ 2Department of Agriculture, Faculty of Agriculture, Universitas \\ Sumatera Utara, Medan, Indonesia \\ ${ }^{3}$ Param Agricultural Soil Surveys (M) Sdn Bhd (PASS), Petaling \\ Jaya, Malaysia \\ ${ }^{4}$ Institute of Biological Sciences, Faculty of Science, Universiti \\ Malaya, Kuala Lumpur, Malaysia
}

Correspondence: UT Pupathy, Department of Agriculture, Faculty of Agriculture, Universitas Sumatera Utara, Medan, Indonesia, Email pupathyut@yahoo.com

Received: December 03, 2020 | Published: December 22, 2020

IV. Due to increased fixation rates of phosphate at low $\mathrm{pH}$, the availability of phosphate to oil palms are reduced.

V. Poor base status in soils, resulting in nutrient deficiencies in oil palms.

VI. As most acid sulfate soils are located within/next to coastal areas, any sea-water intrusion would cause a high salinity problems to oil palms.

VII. Due to low $\mathrm{pH}$ and high salinity, root development in oil palm is impeded.

VIII. Soil ripening is arrested and soil remains soft with poor structures and therefore are poorly drained (Figure 1).

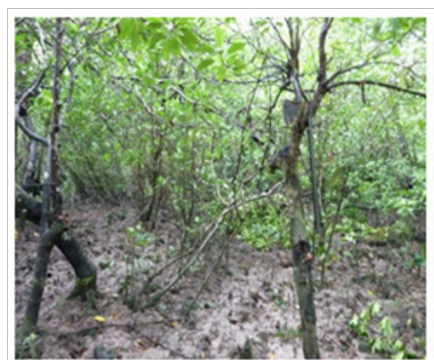

(a)

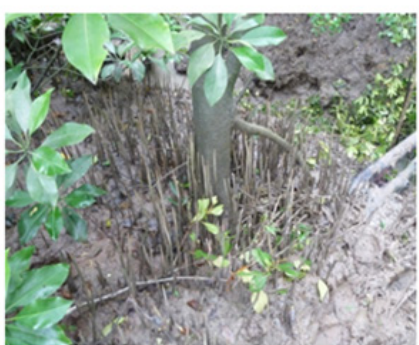

(b)
Figure I Areas under Kranji series in Carey Island (a) in natural condition (b) modification of plant roots (pneumatophores) for survival during flooding or high tid. ${ }^{4}$

\section{Water management practices for managing oil palms on acid sulfate soils}

Early works on importance of managing watertables on acid sulfate soils 
Historically in Malaysia (before 1963, known as Malaya), oil palms were planted by converting rubber areas into oil palm including areas mapped as acid sulfate soils. In early days, oil palms showing hyperacidity symptoms were common in these acid sulfate soils. Kamarudin Ambak et al. ${ }^{11}$ showed and confirmed the typical symptoms of oil palm planted on acid sulfate soils. According to them, oil palms under severe acidic field condition showed numerous desiccated fronds or leaves, especially on older fronds. To improve FFB yield performance of oil palms, a series of experiments involving water management were conducted on acid sulfate soils in Carey Island, Sime Darby (then Harrisons \& Crosfield - Malaysia). In a field trial evaluating the effect of water management on oil palm performance, Toh and Poon (1982) classified acid sulfate soils into three main categories (Table 1). These acid sulfate soils were classified based on the presence of acidic layer that occurs within $120 \mathrm{~cm}$. They highlighted that the acidic layer at 0 to $60 \mathrm{~cm}$ has resulted in severe problems to oil palms. The current soil classification in Peninsular Malaysia also tags this category at 0 to $50 \mathrm{~cm}$ for shallow acid sulfate soils, such as in Linau and Sedu Series (Table 5). Toh et al. ${ }^{12}$ also observed poor FFB yields in severe $(0-60 \mathrm{~cm})$ to moderate $(60-90 \mathrm{~cm})$ category as compared to those of in mild (90-120 cm) and non-acid sulfate areas during 1964-67 period (Table 1).

FFB yield recordings for first consecutive periods of four years (1964-67) shown that average yields were not affected seriously when the acidic layers occurs at $90-120 \mathrm{~cm}$. As the depth of internal drains are rarely exceeding $90 \mathrm{~cm}$ from soil surface, the acidic layer at the depth of $90-120 \mathrm{~cm}$ was not exposed to (i) atmosphere and (ii) very intense drainage. This may be a reason for better performance of oil palms in mild and non-acid sulfate categories. When water table was raised in late 1966, there was only a marginal FFB yield improvement at the acidic layer within the depth of 90-120 cm. However, the substantial FFB yield improvement in severe and moderate acidic areas (during 1968-79) was mainly attributed to ameliorative measure of raising water table in late 1966. These findings had helped the oil palm industry to establish a policy to ensure a network of water management trails on acid sulfate soils. A comparative study was carried out by Hew et al. ${ }^{6}$ on evaluating the oil palm response to the effects of raising watertable. Watertable was raised for 1951 and 1961 plantings, respectively at $14^{\text {th }}$ and $6^{\text {th }}$ of planting year in late 1966 . They showed that FFB yields in 1952 plantings were significantly lower in the acidic soils than those of non-acidic soils (Table 2). In a field experiment, early yields of 1961 plantings also continuously recorded low FFB production in acidic areas compared to non-acidic areas. The palms in acidic areas from the 1964 plantings were only subjected to two years of free drainage and by end 1966, the watertable was raised by blocking the drains to cover the acidic layers. FFB production from 1964 plantings on acidic areas was as good as the non-acidic areas. This suggested that the impact of soil acidity levels on the oil palm was reduced by a mere control on watertable in the field blocks.

The acid sulfate soils in this experiment were drained for about 14 years before the watertable was raised up to a level and maintained to cover the pyritic layer. Maintaining watertable just above the pyritic layer led to a remarkable recovery of oil palms in the acidic areas as shown in Table 3. In a nutshell, findings of this experiment also revealed the importance of water management in recovering the oil palm from the hyperacidity symptoms. A comparative study was also carried out by Hew et al. ${ }^{6}$ on the length, fresh weight and leaf area of frond 17 of oil palms in the acidic and non-acidic areas on 1961 and 1964 plantings. The results indicated that all vegetative measurements were smaller in acidic areas in the 1961 plantings. However, all vegetative measurements on acidic areas were improved and comparable those of in 1964 plantings (Table 3). Due to raising watertable in late 1966, vegetative measurements taken from plots of acidic areas were always greater than those of acid control plots for 1964 plantings. With the introduction of water management policies on acidic areas, the performance of oil palm in the acidic areas were comparable to those of non-acidic areas as shown in Table 2 and Table 3.

Table I Details on category of acidity and FFB yield in consecutive periods of four years from 1968-197912

\begin{tabular}{lllllll}
\hline Category of acidity & Depth of acidic layer $\mathbf{( c m})$ & Ha & \multicolumn{5}{l}{ FFB Yield (tones/ha/year) } \\
\hline & & & $1964-67$ & $1968-7 \mid$ & $1972-75$ & 1976-79 \\
\hline Severe & $0-60$ & 273 & 11.44 & 15.59 & 17.52 & 18.06 \\
Moderate & $60-90$ & 366 & 16.38 & 19.27 & 19.08 & 18.98 \\
Mild & $90-120$ & 12 & 22.81 & 23.43 & 22.14 & 17.32 \\
Non-acid sulfate & - & 888 & 23.89 & 24.14 & 22.44 & $20.4 \mid$ \\
\hline
\end{tabular}

Table 2 FFB production in acidic and non-acidic experimental areas $(\mathrm{kg} / \text { palm/annum })^{4}$

\begin{tabular}{|c|c|c|c|c|c|c|c|c|c|}
\hline \multirow[t]{2}{*}{ Year from planting } & \multicolumn{3}{|c|}{ I952 plantings + } & \multicolumn{3}{|c|}{ |96 | Plantings* } & \multicolumn{3}{|c|}{ I 964 Plantings\# } \\
\hline & Acid Control & Acid & Non-Acid & Acid Control & Acid & Non-Acid & Acid Control & Acid & Non-Acid \\
\hline 4 & 58.5 & 58.5 & 71.2 & 37.2 & 35 & 133.3 & 119.6 & 160 & 157.8 \\
\hline 5 & 88.8 & 88.8 & 105.1 & 67.8 & 71 & 191.1 & 147.4 & 204 & 197.7 \\
\hline 6 & 123.9 & 123.9 & 168.2 & 77 & 86 & 197.7 & 163.9 & 187 & 196 \\
\hline 7 & 120.2 & 120.2 & 212.5 & 115.7 & 118 & 242.4 & 153.9 & 183 & 209.1 \\
\hline 8 & 152.9 & 152.9 & 189.3 & 145.5 & 145.7 & 244.7 & 123.3 & 155 & 194 \\
\hline 9 & 147.6 & 147.6 & 176.7 & 146.5 & 168 & 242.1 & - & - & - \\
\hline 10 & $|4| .6$ & $14 \mid .6$ & 224.3 & 162.7 & 189 & 231.1 & - & - & - \\
\hline II & 109.8 & 109.8 & 239.4 & | 47.7 & 173 & 221.9 & - & - & - \\
\hline
\end{tabular}


Table continued...

\begin{tabular}{|c|c|c|c|c|c|c|c|c|c|}
\hline \multirow[t]{2}{*}{ Year from planting } & \multicolumn{3}{|c|}{ I 952 plantings + } & \multicolumn{3}{|c|}{ |96 | Plantings* } & \multicolumn{3}{|c|}{ I 964 Plantings\# } \\
\hline & Acid Control & Acid & Non-Acid & Acid Control & Acid & Non-Acid & Acid Control & Acid & Non-Acid \\
\hline 12 & 101.2 & 101.2 & 269 & - & - & - & - & - & - \\
\hline 13 & 68.7 & 68.7 & 237 & - & - & - & - & - & - \\
\hline 14 & 60.8 & 66.2 & 223.1 & - & - & - & - & - & - \\
\hline 15 & 78.6 & 93 & 224.7 & - & - & - & - & - & - \\
\hline 16 & 75.3 & 124 & 225.6 & - & - & - & - & - & - \\
\hline 17 & $1 \mathrm{II} .4$ & 174 & 204.8 & - & - & - & - & - & - \\
\hline 18 & 107.2 & 165 & 200.2 & - & - & - & - & - & - \\
\hline 19 & 105.2 & 166 & 226.2 & - & - & - & - & - & - \\
\hline
\end{tabular}

+ Yields of palms in these plantings from the $4^{\text {th }}$ to the $13^{\text {th }}$ year for the acid control and acid fertilized areas were the same since these were from the same fields before the experiments began. * Watertable raised after 5 years. \# Subjected to 2 years of free draining and watertable was raised in late 1966.

Table 3 Growth of oil palms (as indicated by Frond 17) in acidic and non-acidic experimental areas ${ }^{4}$

\begin{tabular}{|c|c|c|c|c|c|c|c|}
\hline \multirow[t]{2}{*}{ Frond I 7} & \multirow[t]{2}{*}{ Year of Planting } & \multicolumn{3}{|l|}{ I96 I Plantings } & \multicolumn{3}{|l|}{ I 964 Plantings } \\
\hline & & Acid Control & Acid & Non-Acid & Acid Control & Acid & Non-Acid \\
\hline Length & 4 & 388 & 385 & 453 & 418 & 437 & 484 \\
\hline \multirow[t]{5}{*}{$(\mathrm{cm})$} & 5 & 398 & 403 & 494 & 469 & 487 & 521 \\
\hline & 6 & 399 & 401 & 545 & 492 & 526 & 535 \\
\hline & 7 & 412 & 418 & 540 & 511 & 541 & 561 \\
\hline & 8 & 427 & 443 & 539 & 561 & 595 & 588 \\
\hline & $9 *$ & 457 & 468 & 569 & - & - & - \\
\hline Fresh Wt. & 4 & 2.39 & 2.32 & 3.58 & 2.55 & 2.67 & 2.39 \\
\hline \multirow[t]{5}{*}{$(\mathrm{kg})$} & 5 & 2.71 & 2.65 & 4.7 & 3.35 & 3.72 & 4.08 \\
\hline & 6 & 2.73 & 2.58 & 5.71 & 4.12 & 4.84 & 5.15 \\
\hline & 7 & 2.94 & 2.99 & 6.12 & 4.46 & 5.28 & 6.09 \\
\hline & 8 & 3.16 & 3.3 & 5.91 & 5.49 & 6.49 & 6.49 \\
\hline & $9 *$ & 3.69 & 3.97 & 7.06 & - & - & - \\
\hline Leaf area & 4 & 3.9 & 3.9 & 4.9 & 4.1 & 4.4 & 5.2 \\
\hline \multirow[t]{5}{*}{$\left(m^{2}\right)$} & 5 & 4.2 & 4.2 & 6.3 & 5.1 & 5.6 & 6.3 \\
\hline & $6 *$ & - & - & 7.6 & 6.2 & 6.3 & 7.5 \\
\hline & 7 & 4.8 & 5 & 7.8 & 6.4 & 7 & 8.6 \\
\hline & 8 & 5.5 & 5.7 & 8.1 & 7.4 & 8.3 & 9.2 \\
\hline & $9 *$ & 5.9 & 6.5 & 9.3 & - & - & - \\
\hline
\end{tabular}

*Data not available

Soil- water relationship on acid sulfate soils.

Soil- water relationship on acid sulfate soils

Aluminium (Al) solubility and its toxicity to any plants are pronounced at low soil $\mathrm{pH}$. Throughout the formation period of acid sulfate soils, the cations such as $\mathrm{Mg}, \mathrm{Ca}$ and $\mathrm{K}$ are commonly leached out slowly and replaced by aluminium and hydrogen ion in the exchange complex, resulting in multiple nutrient deficiencies at variable degrees in oil palm. Turner et al. ${ }^{13}$ have described the symptoms of Al toxicity in the oil palm under drained and oxidized acid sulfate soil conditions. They found such symptoms have almost disappeared by raising the watertable. Generally, there would be a build-up of acidity in the drain water due to presence of accumulated Al. Poon et al. ${ }^{1}$ further emphasized that the periodic flushing of the drains on acid sulfate soils is needed to remove the accumulated toxic polyvalent ions such as $\mathrm{Al}^{3+}$ and the extremely acidic water. Hence, wet season should be identified in order to allow flushing of drain water by opening all water retention blocks and water gates in the drains (Figure 3). Jamaluddin $\mathrm{N}$ et al. ${ }^{14}$ highlighted that one or two rounds of flushing during the wet season are sufficient to reduce the 
problems of acidity and as well as salinity in oil palm. Before the end of the wet season, the blocks and water gates are closed to allow fresh water to build up to the required level, for an example to retain water level up to $50 \mathrm{~cm}$ from soil surface for Linau and Sedu series in Malaysia (Figure 2). For this purpose, a proper water management was implemented in Malaysia and Indonesia for sustaining FFB yield in all acid sulfate soils. ${ }^{15} \mathrm{~A}$ typical dimension of drains is given in Table 4. Location of the different types of drains in typical acid sulfate areas is shown in Figure 3.

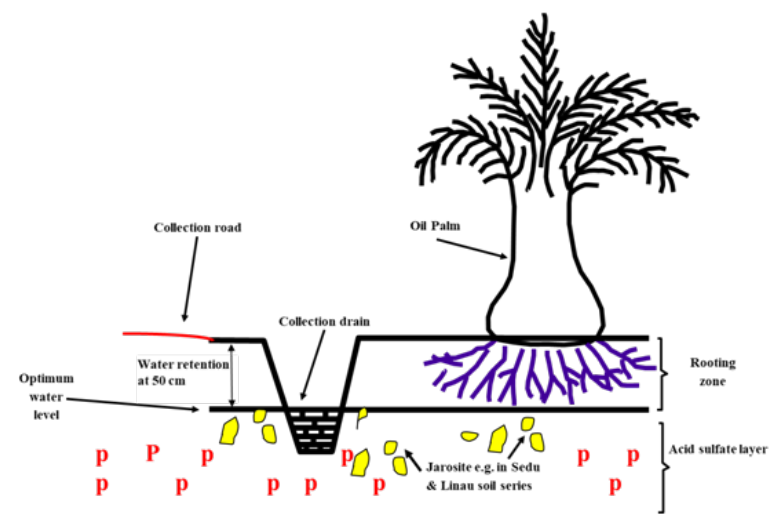

Figure 2 Managing water level for oil palms grown on acid sulfate soils by keeping watertable above the layers of pyrite $(P)$ and jarosite $(\square){ }^{4}$

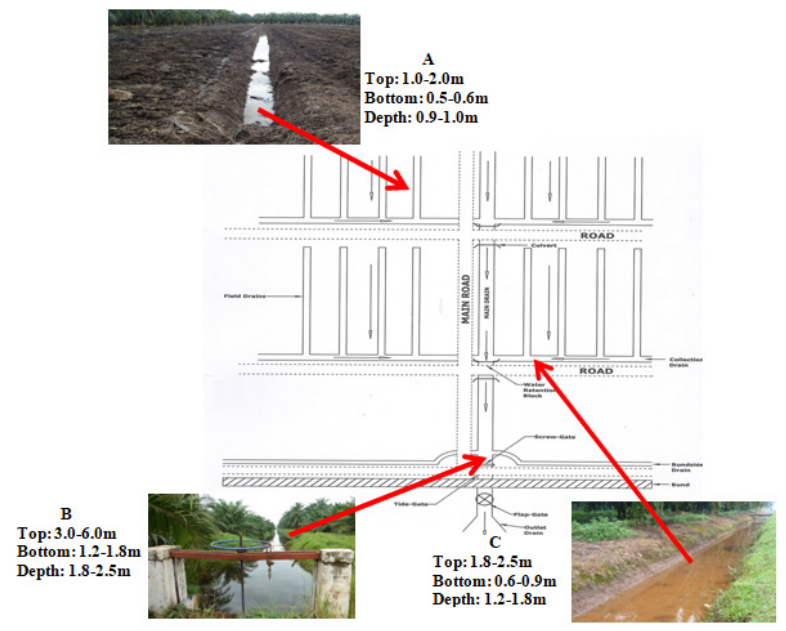

Figure 3 Layout plan of the drainage system in acid sulfate soils. ${ }^{4}(A)$ : subsidiary /in-field, (B) collection and (C) main drains.

Toh et al. ${ }^{12}$ highlighted that FFB yield was increased up to the range of 25 to $30 \mathrm{tFFB} /$ ha per year on acid sulfate soil, with implementation of improved agronomic practices and water management programme. They also emphasized that such high FFB yields were achieved in oil palms as there was no drought stress throughout the trial period. Frequent flushing of drain water also resulted in improved FFB yields in oil palms planted on saline and acidic areas. Abdul Razak et al. ${ }^{16}$ reported that on newly reclaimed areas which are highly influenced by saline and acidic water, oil palm performance and its FFB yields were improved satisfactorily especially after seven years of field planting. This FFB yield improvement was attributed mainly to the frequent flushing of saline and acidic water by providing adequate drain networks and good agronomic inputs. Drainage network in salineaffected areas is similar to those shown in Figure 3. Acid sulfate soil is known for its heavy texture and generally occurs in low-lying areas.
Therefore, it is important to implement an extensive drainage system to remove any excess water, prior to oil palm cultivation. However, a free drainage would also results in the intensification of acidity as pyritic layers are exposed to atmosphere. In both situations, if not taken adequate care, there would be an adverse effect on the oil palm performance and its FFB yields. As such, problems on management of oil palms on acid sulfate soils are two-fold. Basics on managing water level in the drain for oil palm grown on acid sulfate soils are illustrated in Figure 2. A network of drainage which was introduced in 1960's, still being practiced nowadays for the betterment of oil palm production in these problematic soils in Carey Island and other acid sulfate soil areas in Malaysia as well as in Indonesia. The growth of oil palms on acid sulfate soils was inferior. As a result, FFB production was extremely poor as compared to those of planted on non-acid sulfate soils. In the late 1960's and 1970's, Hew et al. ${ }^{6}$ had initiated several trials for evaluating the oil palm responses to the effects of liming and manuring rates, especially for oil palms planted on acid sulfate soils at Oil Palm Research Station (OPRS), Banting, Selangor, Malaysia (then in OPRS, Harrisons \& Crosfield). They found that oil palms on acid sulfate soils were responded positively to applications of fertilisers and improved further in terms of growth and bunch yields.

\section{Suggested methods for raising watertable}

As illustrated in Figure 3, a network of drains comprising subsidiary/in-field, collection and main drains should be established for controlling and raising watertable effectively on acid sulfate soils. All subsidiary drains should be connected to the collection drains and all collection drains should be connected to main drains eventually. A marker should be placed at strategic location in the collection drains as shown in Figure 5 (A \& B) for assisting the management to monitor the watertable. Water level at the interior areas of oil palm fields would be at the similar level as in the collection drains. A color code system for monitoring the watertable also proposed to use, such as green, white and red to indicate the ranges of watertable at the extremely low, desired level and extremely high respectively. In order to have smooth and faster removal of water especially during raining season, all types of drains should be cleared and free from any weeds Figure 5 (C).

\section{FFB yield achievement on acid sulfate soils}

\section{Moving forward for a higher FFB yields on acid sulfate soils}

The growth of oil palms on acid sulfate soils was inferior. As a result, FFB production was extremely poor as compared to those of planted on non-acid sulfate soils. In the late 1960's and 1970's, Hew et al. ${ }^{17}$ and Hew et al. ${ }^{6}$ had initiated several trials for evaluating the oil palm responses to the effects of liming and manuring rates, especially for oil palms planted on acid sulfate soils at Oil Palm Research Station (OPRS), Banting, Selangor, Malaysia (then in OPRS, Harrisons \& Crosfield). They found that oil palms on acid sulfate soils were responded positively to applications of fertilisers and improved further in terms of growth and bunch yields. Hew et al. ${ }^{17}$ also studied on the oil palm responses to the different rates of liming application. They revealed that due to high buffering capacity of soils (mainly Selangor, Jawa and Sedu series), liming activity was not effective to overcome the impacts of soil acidity for oil palms grown on acid sulfate soils. They found that the reduction in soil $\mathrm{pH}$ was a temporary phenomenon and need to carryout liming annually at rates, higher than $6 \mathrm{mt} / \mathrm{ha}$. Liming also had increased leaf $\mathrm{Mg}$ and leaf $\mathrm{Ca}$ level which eventually reduced leaf $\mathrm{K}$ levels in oil palms due to antagonistic effects of $\mathrm{K}$ and $\mathrm{Mg} /$ Ca. Nevertheless by early 1970 s, Poon et al. ${ }^{7}$ showed that by having 
an anaerobic condition with a network of drains, the development of soil acidity is arrested economically. However, inadequate drainage would also cause a flooded condition which also adversely affect palm performance. The oil palm roots are generally not grow beyond the rooting zone. Therefore a balance has to be struck between overdrainage and under-drainage by controlling the water-table at about $60 \mathrm{~cm}$ from the surface. This balance is achieved through a network of drains namely field, collection and main drains as shown in Figure 3 and Table 4.

Table 4 Dimension of drains in acid sulfate soils

\begin{tabular}{llll}
\hline Type of Drain & \multicolumn{2}{l}{ Width $(\mathrm{m})$} & Depth $(\mathbf{m})$ \\
\hline & Top & Bottom & \\
\hline Field & $1.0-2.0$ & $0.5-0.6$ & $0.9-1.0$ \\
Collection & $1.8-2.5$ & $0.6-0.9$ & $1.2-1.8$ \\
Main & $3.0-6.0$ & $1.2-1.8$ & $1.8-2.5$ \\
\hline
\end{tabular}

Raising the watertable is an important management tool for managing oil palms on acid sulfate soils. Raising watertable to cover the pyritic layers within sulfuric soil horizons would inhibit oxidation and thus further acidification in soils. A list of soils series with details on sulfidic materials, yellowish jarosite \& yellowish brown mottles and layers of organic materials are illustrated in Figure 4 \& Table 5 in Appendix 1. An understanding on the location of pyritic layers,

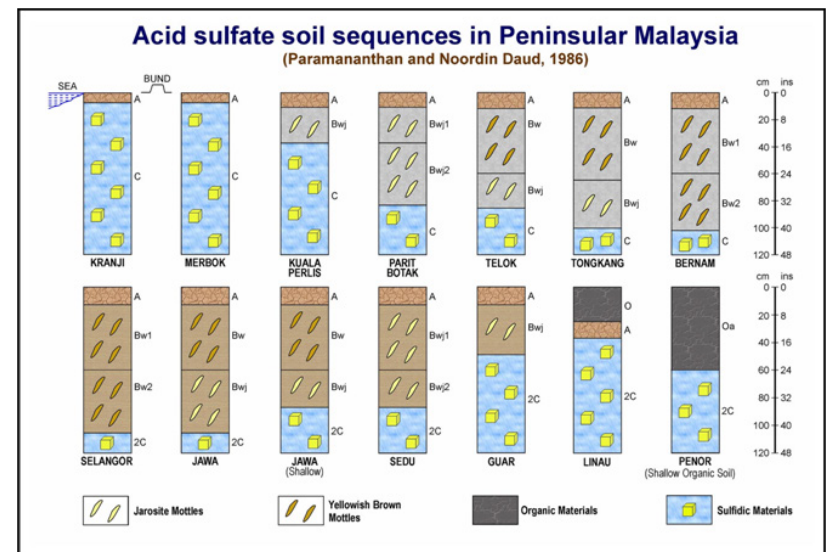

Figure 4 Acid Sulfate Soil Sequence in Peninsula Malaysia. ${ }^{2}$ Water need to be maintained from soil surface at least $45 \mathrm{~cm}$ onwards in order to cover all pyritic layers, jarosites and sulfidic materials.

its depth and identification of potential as well as true acid sulfate soils are necessary for managing these acid sulfate soils for growing oil palm. The objective of this controlled drainage is to maintain the watertable at 45 to $60 \mathrm{~cm}$ from soil surface and should not exceeding $75 \mathrm{~cm}$ depth. Exceeding $75 \mathrm{~cm}$ from soil surface would be a risk for causing an accelerated oxidation of the pyrite layer during dry weather condition.

Table 5 Key to the identification of potential (sulfidic materials) and true acid sulfate (sulfuric horizon) soils

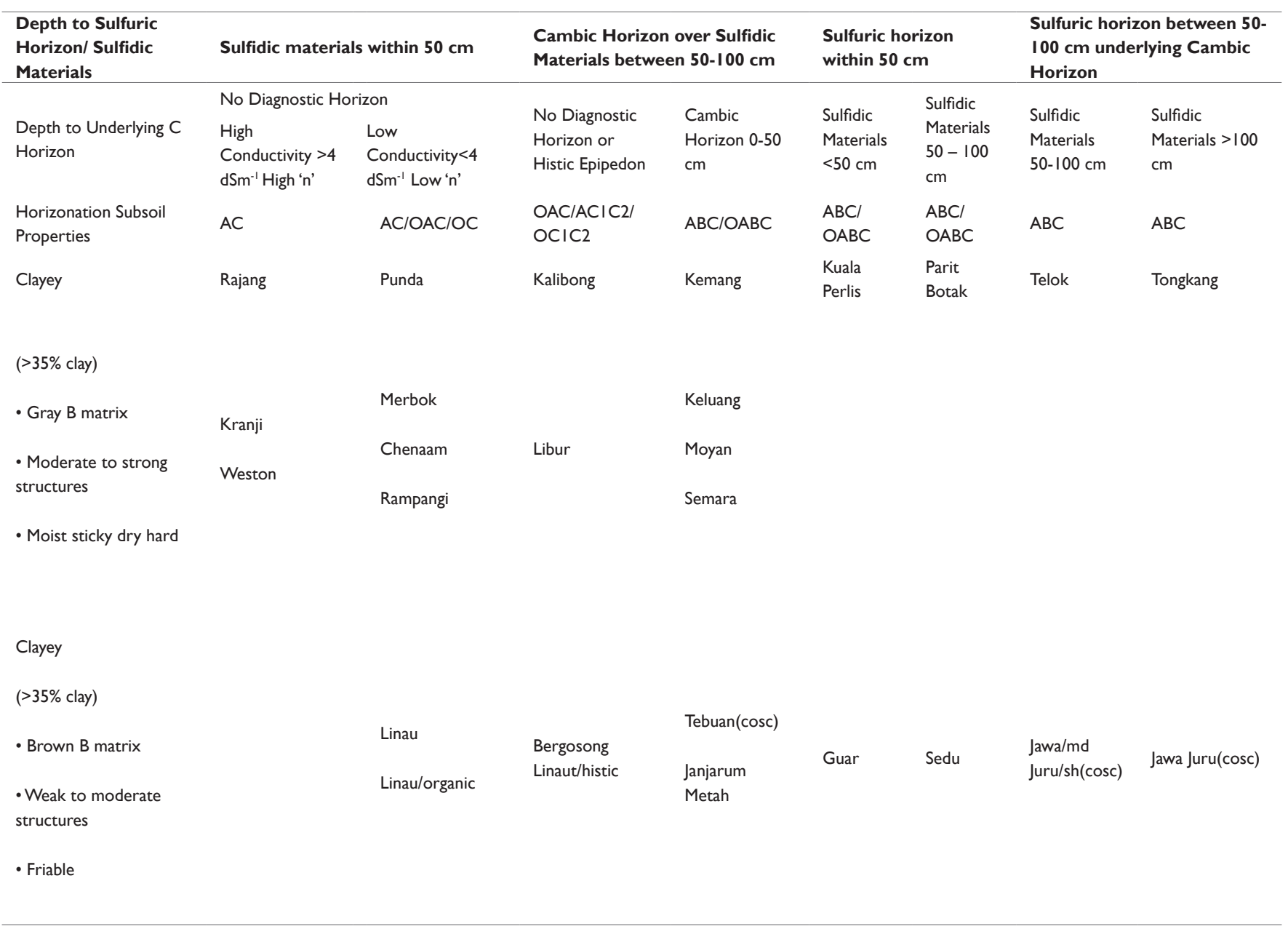


Table continued...

\begin{tabular}{|c|c|c|c|c|}
\hline $\begin{array}{l}\text { Depth to Sulfuric } \\
\text { Horizon/ Sulfidic } \\
\text { Materials }\end{array}$ & Sulfidic materials within $50 \mathrm{~cm}$ & $\begin{array}{l}\text { Cambic Horizon over Sulfidic } \\
\text { Materials between } 50-100 \mathrm{~cm}\end{array}$ & $\begin{array}{l}\text { Sulfuric horizon } \\
\text { within } 50 \mathrm{~cm}\end{array}$ & $\begin{array}{l}\text { Sulfuric horizon between } 50 \text { - } \\
100 \mathrm{~cm} \text { underlying Cambic } \\
\text { Horizon }\end{array}$ \\
\hline $\begin{array}{l}\text { Loamy } \\
\text { (10-35\% clay) }\end{array}$ & $\begin{array}{l}\text { Nagor(scl) } \\
\text { Nangka (sl) (Sr) }\end{array}$ & \multicolumn{2}{|c|}{ Tambun(scl) Timun(sl) } & Carey Jawa (scl) \\
\hline
\end{tabular}

Sandy

$(<10 \%$ clay $) \quad$ Belat Pandak Mersan

$(>70 \%$ sand $)$

(Source: Pupathy and Paramananthan, 20I4- Revised S. Paramananthan, Updated 2020)

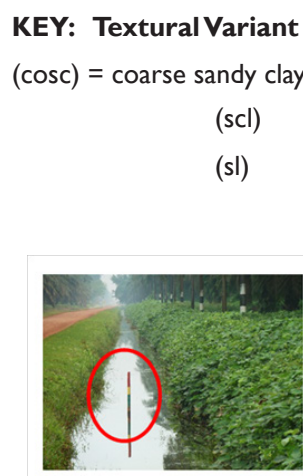

(a)

\section{Phases Location}

sh: shallow $(\mathrm{Sr})=$ Sarawak

= sandy clay loam

= sandy loam

Figure 5 (A \& B) Position of water-level marker (in circle) for monitoring watertable on collection drains and (c) removal of debris and cleaning of collection drains.

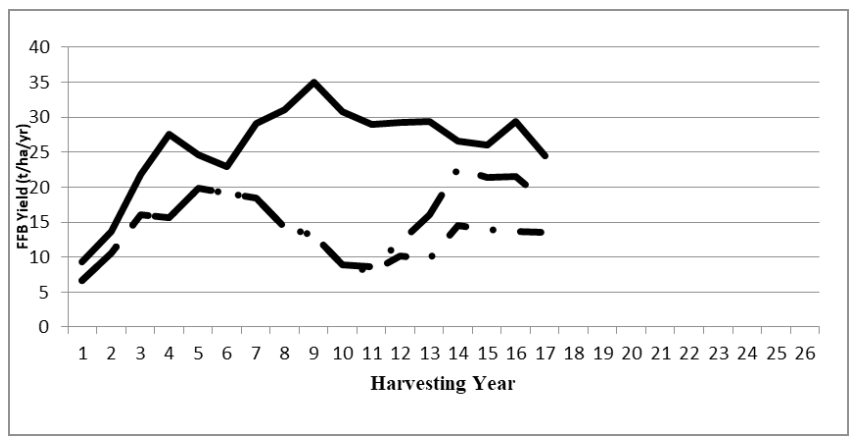

Figure 6 Effect of water management on FFB production in oil palm planted on acid sulfate soils. ${ }^{6}$

\section{Commercial FFB yields in Malaysia and Indonesia}

Based on the fact findings and trial results as shown above, an improved high FFB yields was achieved at commercial scale in Malaysia and Indonesia. This FFB yield increment was attributed to controlling of watertable at $45-60 \mathrm{~cm}$ below soil surface. ${ }^{5}$ Figure 6 shows the actual FFB yields which were dramatically improved as a result of implementation of maintaining watertable at $45-60 \mathrm{~cm}$ below soil surface and implementation of agro- management practices such as EFB \& POME application and inorganic fertilizer application. Commercial scale FFB yield production as obtained on a few fields of acid sulfate soils in Carey Island, Malaysia are given in Appendix II. Pupathy et al. ${ }^{5}$ reported an improved FFB yields at commercial scale in Indonesia, by implementing proper water and nutrition management. He reported that FFB yields of above $30 \mathrm{mt} / \mathrm{ha}$ were

achieved from oil palms that grown on acid sulfate soils in Sumatera, Indonesia. In TPAI Estate (South Sumatra, Indonesia) FFB yields of above 27 tonne/ha/year at the eighth harvesting year was attained as shown in Figure 7. By covering the pyritic horizon with watertable at $45-60 \mathrm{~cm}$ from soil surface, higher FFB yields were achieved on acid sulphate soils in both Malaysia and Indonesia. ${ }^{18,19}$

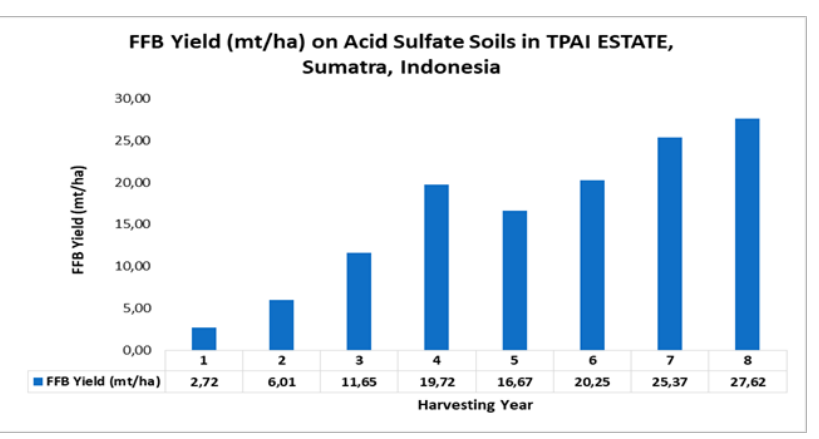

Figure 7 FFB production in oil palm planted on acid sulphate soils in TPAI Estate, Sumatra, Indonesia for the period of 2012-2019.5

\section{Conclusion}

The presence of sulphuric soil material or a sulphuric horizon in acid sulfate soils limits the soil potential for oil palm cultivation. Agricultural use of these acid sulfate soils has to be based on cautious water management in order to prevent oxidization processes of pyrite. Nowadays, yields above $35 \mathrm{mt} / \mathrm{ha}$ are not uncommon for oil palms grown on acid sulfate soils. With proper water and fertilizer management, high FFB yields are achievable and comparable to palms that grown on some best soil types in Malaysia as well as in Indonesia. Raising the watertable to cover the pyritic horizon in order to inhibit further oxidation would be an important management tool for managing oil palms on acid sulfate soils.

\section{Acknowledgements}

None.

\section{Conflicts of interest}

The author declares there is no conflict of interest. 


\section{References}

1. Poon YC, Chang AK. The chemistry and fertility of acid sulfate soils, in Proceedings of the Seminar on the Chemistry and Fertility of Malaysian soils. 1979

2. Paramananthan S, Noordin Daud. Classification of Acid Sulfate Soils of Peninsular Malaysia. In Pertanika. 1986;9(3):323-330.

3. Shamshuddin J, Paramananthan S. Acidity and Charge Characteristics of Marine Alluvial Soils from Carey Islands, Selangor. In Pertanika. 1988;11(1):15-23.

4. Pupathy UT, Paramananthan S. Agro-management for oil palms planted on acid sulfate soils. In: Selected Papers on Soil Science: Volume 1: Problem Soils, Agricultural Crop Trust. 2014. p. 85-101.

5. Pupathy UT, Sundian N, David AS. Implementation of action plan for improving oil palm performance on acid sulfate soils in Sumatra. Indonesia, Proc. Soil Science Conf. of Malaysia, SOILS 2019, Malacca, 2019. p. 70-73

6. Hew CK, Poon YC, Bloomfield C. The growth and yield responses of oil palms to manuring and watertable control in acid sulfate soils in Peninsula Malaysia. Conf on Chem and Fert of Tropical Soils, Kuala Lumpur. 1974.

7. Poon YC, Bloomfield C. The amelioration of acid sulfate soil with respect to oil palm. Trop Agric. 1977;54(4):289-305.

8. Pons LJ, N van Breemen. Factors influencing the formation of potential acidity in tidal swamps. In Proceedings of the Bangkok symposium on acid sulfate soils, Edited by Dost H. and N. van Breemen, International Institute for Land Reclamation and Improvement/ ILRI, Netherlands. 1982.

9. Paramananthan S. Soil surveys in Peninsular Malaysia- Progress and problems. In the proceedings of Conference on Soil science and agricultural development in Malaysia. Kuala Lumpur. 1980. p. 03-22.

10. Xaviar A. Improvement of oil palm performance on some problem soils: peat and acid sulphate soils. Soil Science Conference of Malaysia, Soils 2005, Sungai Petani, Kedah, 2005. p. 153-157.
11. Kamarudin Ambak, Ting CC, Gopinathan B. Acid Sulfate soils and its utilization in West Johore. In the proceedings of Conference on Soil science and agricultural development in Malaysia. Kuala Lumpur. 1980. p. 81-92.

12. Toh PY, Poon YC. Effect of water management on field performance of oil palms on acid sulfate soils in Peninsular Malaysia. In Proceedings of the Bangkok symposium on acid sulfate soils, Edited by Dost $\mathrm{H}$. and N. van Breemen, International Institute for Land Reclamation and Improvement/ ILRI, Netherlands. 1982. p. 260-271.

13. Turner PD, Bull RA. Diseases and disorders of the oil palm in Malaysia. 1967.

14. Jamaluddin N, Pupathy UT, Abd Rahim Othman. Golden Hope's Experience in Managing Saline Soils for Oil Palm Cultivation. International Planters Conference 17-20 May 2000, Kuala Lumpur. 2000. p. 341-346.

15. Pupathy UT, Sundian N. Key Agronomic Management Factors for Maximising Oil Palm Yields on Acid Sulfate Soils in Malaysia and Indonesia. International Conference on Agriculture, Environment and Food Security (AEFS) 2019, $10^{\text {th }}$ October 2019, Medan-Indonesia. In IOP Conference Series: Earth and Environmental Science. Volume 454 (published on $1^{\text {st }}$ February 2020). 2020

16. Abdul Razak I, Mohd Hashim T, Jamaluddin N. Management of saline soils for oil palm cultivation.In Proceedings of Seminar of MSSS Conference. 1995.

17. Hew CK, Khoo KM. Some methods of improving oil palms on acid sulfate soils in West Malaysia. Proc. $1^{\text {st }}$ ASEAN Soil conference No 38. 1970.

18. Paramananthan S. Managing marginal soils for sustainable growth of oil palms in the tropics. J oil palm \& the environment. 2013;4:1-16.

19. Poon YC. The management of acid sulfate soils - HMPB experience. In: Seminar on Acidsulfate Soils, Kuala Lumpur. MSSS. 1983. 